\title{
PENGARUH PENDIDIKAN KEWIRAUSAHAAN, EFIKASI DIRI, KEPRIBADIAN DAN PERAN FAKTOR KELUARGA TERHADAP NIAT BERWIRAUSAHA
}

\author{
Jonathan Tanazha dan Herlina Budiono \\ Program Studi S1 Manajemen Fakultas Ekonomi Dan Bisnis Universitas Tarumanagara, Jakarta \\ jonathan.115170258@stu.untar.ac.id
}

\begin{abstract}
The purpose of this study was to examine the effect of entrepreneurship education, self-efficacy, personality and the role of family factors on entrepreneurial intentions. The data collection technique used a questionnaire distributed online through social media in the form of Whatsapp, Line and Instagram. The number of samples used in this study were 100 respondents who were students of Universitas Tarumanagara. The sample selection technique in this study was purposive sampling. The data analysis technique used the PLS-SEM method. The results showed that entrepreneurship education, self-efficacy, personality and the role of family factors had a positive and significant effect on entrepreneurial intentions.
\end{abstract}

Keywords: Entrepreneurship Education, Self-Efficacy, Personality, Role of Family Factors, Entrepreneurial Intentions.

Abstrak: Tujuan dari penelitian ini untuk menguji pengaruh antara pendidikan kewirausahaan, efikasi diri, kepribadian dan peran faktor keluarga terhadap niat berwirausaha. Teknik pengumpulan data menggunakan kuesioner yang disebarkan secara online melalui media sosial berupa Whatsapp, Line dan Instagram. Jumlah sampel yang digunakan dalam penelitian ini sebanyak 100 responden yang merupakan mahasiswa/i Universitas Tarumanagara. Teknik pemilihan sampel pada penelitian ini adalah purposive sampling. Teknik analisis data menggunakan metode PLS-SEM. Hasil penelitian menunjukkan pendidikan kewirausahaan, efikasi diri, kepribadian dan peran faktor keluarga berpengaruh positif dan signifikan terhadap niat berwirausaha.

Kata kunci: Pendidikan Kewirausahaan, Efikasi Diri, Kepribadian, Peran Faktor Keluarga, Niat Berwirausaha.

\section{LATAR BELAKANG}

Pada era sekarang ini persaingan untuk mencari pekerjaan terus meningkat dari tahun ke tahun, hal ini juga terjadi bersamaan dengan bertambahnya jumlah populasi penduduk di Indonesia, BPS (2020) diperkirakan jumlah pengangguran di Indonesia sebesar 9,77 juta jiwa dengan persentase $7,07 \%$ dan bertambah 2,67 juta dibanding tahun lalu yaitu 7,10 juta jiwa. Farrukh et al. (2017) menjelaskan bahwa tingginya tingkat pengangguran dikarenakan banyak mahasiswa yang telah lulus lebih memilih untuk mencari pekerjaan ketimbang membuka usaha sendiri. Menjadi seorang wirausahawan tidaklah harus bergantung pada jenjang pendidikan yang dicapai tetapi juga dapat melalui niat dari individu tersebut. Dengan membuka lapangan 
pekerjaan baru dan meningkatkan niat berwirausaha individu sejak dini, sehingga dapat mengurangi pengangguran yang terjadi di Indonesia.

Aparicio (2016) menyatakan kewirausahaan sangatlah penting bagi perkembangan perekonomian individu dan nasional. Karena itu, kewirausahaan diberikan banyak peluang untuk mendapatkan kebebasan dan keuntungan finansial. Diperlukan sebuah cara agar seseorang dapat meningkatkan niatnya dalam berwirausaha dan menjadi seorang wirausahawan, sebagai solusi untuk menurunkan angka pengangguran yang terjadi di Indonesia. Terdapat beberapa faktor yang dapat membentuk niat seseorang untuk berwirausaha, yaitu pendidikan, efikasi diri, kepribadian dan peran faktor keluarga (Nurchotim, 2012).

Penelitian yang dilakukan oleh Kuratko (2005) menjelaskan bahwa pendidikan kewirausahaan dengan berbagai konteks pendidikan dimaksudkan untuk mengembangkan budaya kewirausahaan, mempromosikan pendirian terhadap usaha baru, dan untuk mendorong pola pikir pada wirausahawan melalui pendidikan dan pembelajaran.

Faktor selanjutnya adalah efikasi diri. Efikasi diri sebagai indikator kepercayaan diri akan menimbulkan sikap yaitu rasa mampu akan mendirikan usaha baru dan kemampuan mengelola usaha. Efikasi diri yang dikemukakan Zhao et al. (2005) menjelaskan bahwa dalam membangun suatu usaha yang baru harus membutuhkan kepercayaan diri yang cukup tinggi dalam membentuk dan menjalankan usaha yang dibentuk agar dapat berjalan dengan baik.

Kemudian faktor berikutnya ialah kepribadian. Rauch dan Frese (2007) menjelaskan bahwa kepribadian merupakan sifat seseorang dari situasi / kondisi yang terjadi dengan menunjukkan ciri khas tertentu dari waktu ke waktu, hal ini dapat membantu mengamati bagaimana kecenderungan individu memiliki niat untuk menjadi wirausahawan.

Selain itu terdapat faktor berikutnya, yaitu peran faktor keluarga. Keluarga memiliki peran yang sangat penting terhadap keyakinan, harapan dan rencana karier seorang anak di masa depan nanti. Ergeneli (2014) menyebutkan bahwa anggota keluarga memiliki peran yang sangat penting dalam memberikan dukungan dan inspirasi antara satu anggota keluarga dengan yang lainnya.

Berdasarkan latar belakang yang telah dijelaskan dan untuk melengkapi berbagai penelitian, maka dilakukan penelitian dengan subjek penelitian yaitu mahasiswa / mahasiswi aktif S1 (Sarjana) di Universitas Tarumanagara dan menjadikan pendidikan kewirausahaan, efikasi diri, kepribadian dan peran faktor keluarga sebagai prediktor dari niat berwirausaha. Penelitian ini dilakukan untuk mempelajari apakah variabel yang digunakan memiliki dampak terhadap subjek yang akan diteliti.

\section{KAJIAN TEORI}

Acuan teori yang digunakan adalah teori perilaku terencana atau TPB (Theory of Planned Behaviour) teori ini merupakan pengembangan dari teori beralasan (Theory of reasoned action). Theory of Planned Behavior yang dikemukakan Ajzen (2005) didasarkan pada asumsi yang dilakukan oleh manusia yang berperilaku dengan cara yang masuk akal, seperti mempertimbangkan atau memperhitungan informasi yang ada secara implisit atau eksplisit. Tujuan dari Theory of Planned Behavior oleh Ajzen (1985) adalah untuk memprediksi perilaku seorang individu secara lebih spesifik.

TPB (Theory of Planned Behaviour) mengarah pada niat dalam berwirausaha, ini terjadi karena niat pada individu dapat berubah menjadi sebuah perilaku dari individu tersebut. Karabulut (2016) menjelaskan bahwa niat berwirausaha didasarkan oleh visi, perasaan dan 
mimpi untuk dapat berwirausaha, pengembangan rencana bisnis, akuisisi dalam sumber daya dan perilaku yang telah diarahkan ke tujuan. Niat untuk berwirausaha berarti dapat muncul melalui adanya kemauan untuk membuat usaha, perencanaan usaha bisnis dengan tujuan usaha dalam diri seseorang.

Pendidikan Kewirausahaan. Alma (2013:6) menjelaskan pendidikan kewirausahaan bertujuan untuk membentuk suatu individu secara utuh, sebagai individu yang memiliki karakter, pemahaman dan keterampilan sebagai wirausaha. Ini merupakan suatu perwujudan dari TPB (Theory of Planned Behaviour) sebagai sebuah acuan seorang individu dalam niat berwirausaha. Penelitian yang dilakukan oleh Lestari dan Wijaya (2012) menemukan adanya pengaruh positif antara pendidikan kewirausahaan terhadap niat berwirausaha.

Efikasi Diri. Bandura (1977) menyebutkan bahwa efikasi diri merupakan keyakinan seseorang berdasarkan motivasional, kognitif dan tindakan dapat berhasil menjalankan suatu perilaku yang diinginkan untuk mencapai suatu hasil. Teori ini didukung oleh teori Luthans (2006) yang mendefinisikan keyakinan diri sebagai kepercayaan tentang kemampuan untuk memotivasi, sumber daya kognitif, dan cara bertindak yang diperlukan untuk berhasil melaksanakan tugas dalam konteks tertentu. Penelitian sebelumnya yang dilakukan oleh Puspitaningsih (2017) mengatakan bahwa efikasi diri berpengaruh signifikan terhadap niat berwirausaha.

Kepribadian. Ginting (2015) mengatakan bahwa kepribadian adalah keseluruhan karakteristik seorang individu bisa berbentuk pikiran, kata hati, perasaan, watak dan emosi. Seorang wirausaha yang sukses memiliki karakteristik kepribadian yang khusus yang dapat membedakannya dari orang lain. Dengan kepribadian yang dimiliki oleh seseorang dapat menarik dan memikat hati orang lain karena kepribadian yang dirasakan berbeda. Penelitian yang dihasilkan oleh Aprilianty (2012) telah menyatakan bahwa kepribadian memiliki pengaruh yang positif dan signifikan terhadap niat berwirausaha.

Peran Faktor Keluarga. Periera et al. (2017) menyebutkan bahwa peran faktor keluarga dapat menentukan tinggi rendahnya niat seorang individu dalam melakukan wirausaha. Individu yang memiliki niat untuk berwirausaha, pasti memerlukan dukungan dari keluarganya sehingga dapat menjadi pendorong dalam niat berwirausaha. Teori ini didukung oleh Histrich (2008) yang menjelaskan bahwa niat berwirausaha pada individu dipengaruhi oleh lingkungan keluarga, teman dan aktivitas dari individu tersebut, hal ini memiliki keterkaitan dengan TPB (Theory of Planned Behaviour), dimana seorang individu dapat menilai sesuatu dan kemudian mengambil keputusan memiliki niat untuk menjadi seorang wirausahawan. Triani (2010) menyatakan bahwa faktor keluarga memberikan hasil positif terhadap niat berwirausaha.

Berdasarkan kajian teori yang ada, model kerangka pemikiran niat berwirausaha pada mahasiswa disajikan secara visual pada gambar 1 dibawah ini:

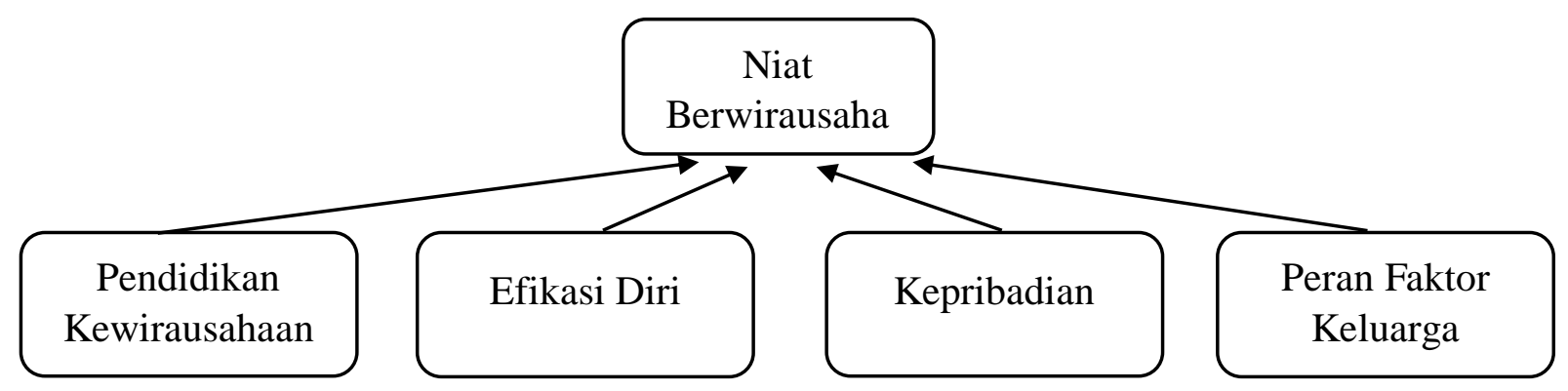

Gambar 1. Model Penelitian 
Berdasarkan kerangka pemikiran yang telah diuraikan, maka dapat dirumuskan hipotesis untuk penelitian ini, yaitu:

H1: Pendidikan kewirausahaan berpengaruh positif terhadap niat berwirausaha mahasiswa Universitas Tarumanagara.

H2: Efikasi diri berpengaruh positif terhadap niat berwirausaha mahasiswa Universitas Tarumanagara.

H3: Kepribadian berpengaruh positif terhadap niat berwirausaha mahasiswa Universitas Tarumanagara.

H4: Peran faktor keluarga berpengaruh positif terhadap niat berwirausaha mahasiswa Universitas Tarumanagara.

\section{METODOLOGI}

Hasil penelitian ini didapatkan dari pembagian kuesioner kepada mahasiswa Universitas Tarumanagara. Penelitian ini berfokus pada niat berwirausaha mahasiswa tersebut. Pemilihan sampel yang dilakukan menggunakan metode purposive sampling. Skala yang akan dipakai adalah skala likert. Menurut Sarwono dan Budiono (2012:69) skala likert adalah skala pengukuran yang menggunakan pernyataan-pernyataan dimana responden diminta merespon terhadap peringkat-peringkat tersebut tersebut. Variabel operasional dalam penelitian ini terdiri dari pendidikan kewirausahaan, efikasi diri, kepribadian dan peran faktor keluarga yang merupakan variabel independen, niat berwirausaha sebagai variabel dependen.

Sudah didapatkan dari responden berupa pengisian kuesioner yang disebar secara online. Berdasarkan data yang didapat dari $100(100 \%)$ responden, sebanyak $52(52 \%)$ responden berjenis kelamin laki-laki dan $48(48 \%)$ responden berjenis kelamin perempuan. Untuk karakteristik jurusan terdapat 29 orang (29\%) adalah jurusan manajemen, 20 orang (20\%) adalah jurusan akuntansi, 7 orang (7\%) adalah jurusan ilmu hukum, 9 orang (9\%) merupakan jurusan arsitektur, 1 orang $(1 \%)$ adalah jurusan mesin, 0 orang $(0 \%)$ adalah jurusan elektro, 9 orang $(9 \%)$ adalah jurusan industri, 7 orang (7\%) adalah jurusan sipil, 0 orang $(0 \%)$ adalah jurusan psikologi, 0 orang $(0 \%)$ adalah jurusan teknik informatika, 0 orang $(0 \%)$ adalah jurusan sistem informasi bisnis, 3 orang (3\%) adalah jurusan desain interior, 6 orang (6\%) orang adalah jurusan desain komunikasi visual, 9 orang (9\%) adalah jurusan ilmu komunikasi, 0 orang $(0 \%)$ adalah jurusan perencanaan wilayah dan kota, 0 orang $(0 \%)$ orang adalah jurusan kedokteran. Untuk karakteristik berdasarkan Angkatan yaitu angkatan 2015 sebanyak 1 orang (1\%), angkatan 2016 sebanyak 6 orang (6\%), angkatan 2017 sebanyak 66 orang (66\%), angkatan 2018 sebanyak 28 orang (28\%), angkatan 2019 sebanyak 0 orang (0\%), angkatan 2020 sebanyak 1 orang (1\%). Untuk karakteristik berdasarkan usia yaitu usia 17-18 tahun sebanyak 1 orang (1\%), usia 19-20 tahun sebanyak 15 orang (15\%), usia 21-22 tahun sebanyak 58 orang (58\%), usia 23-24 tahun sebanyak 25 orang (25\%), usia >26 tahun sebanyak 1 orang (1\%). Untuk karakteristik berdasarkan mahasiswa yang masih aktif kuliah dan telah mengikuti mata kuliah dasar-dasar kewirausahaan, 100 orang menjawab iya (100\%) dan 0 orang menjawab tidak (0\%). 


\section{HASIL UJI STATISTIK}

Hasil Uji Validitas

Sekaran dan Bougie (2016) menyatakan bahwa uji validitas dapat dilakukan dengan dua cara yaitu, convergent validity dan discriminant validity. Convergent validity menggunakan acuan nilai loading factor dan Average Variance Extracted (AVE) dari setiap variabel.

Tabel 1. Hasil Nilai Average Variance Extracted (AVE)

\begin{tabular}{|l|l|}
\hline \multicolumn{1}{|c|}{ Variabel } & AVE \\
\hline Pendidikan Kewirausahaan & 0,638 \\
\hline Efikasi Diri & 0,699 \\
\hline Kepribadian & 0,636 \\
\hline Peran Faktor Keluarga & 0,585 \\
\hline Niat Berwirausaha & 0,700 \\
\hline
\end{tabular}

Sumber: Pengolahan Data SmartPLS 3.0

Hair et al. (2011) menjelaskan hasil nilai AVE harus diatas 0,5. Dari hasil penelitian ini nilai AVE menunjukkan nilai sebesar 0,638 untuk variabel pendidikan kewirausahaan, 0,699 untuk variabel efikasi diri, 0,636 untuk variabel kepribadian, 0,585 untuk variabel peran faktor keluarga, dan 0,700 untuk variabel niat berwirausaha. Selanjutnya, Yamin dan Kurniawan (2011) menjelaskan bahwa suatu indikator dinyatakan valid jika mempunyai nilai loading factor lebih besar dari 0,7, akan tetapi jika 0,5 hingga 0,6 masih dapat diterima. Terdapat beberapa indikator yang tidak memenuhi kriteria loading factor sehingga indikator-indikator tersebut harus dihapuskan.

Tabel 2. Hasil nilai Loading factor

\begin{tabular}{|c|l|c|}
\hline \multicolumn{1}{|c|}{ Indikator } & $\begin{array}{c}\text { Loading } \\
\text { factor }\end{array}$ \\
\hline PK1 & Pendidikan kewirausahaan mengajarkan saya tentang dasar ide bisnis. & 0,716 \\
\hline PK2 & Pendidikan kewirausahaan menumbuhkan niat berwirausaha saya. & 0,843 \\
\hline PK3 & $\begin{array}{l}\text { Pendidikan kewirausahaan menambahkan ilmu dan wawasan saya } \\
\text { dalam bidang wirausaha. }\end{array}$ & 0,784 \\
\hline PK4 & $\begin{array}{l}\text { Pendidikan kewirausahaan memberikan kesadaran kepada saya tentang } \\
\text { peluang bisnis. }\end{array}$ & 0,844 \\
\hline ED1 & Saya memiliki kepercayaan diri dalam mengelola sebuah usaha. & 0,815 \\
\hline ED2 & Saya memiliki kematangan mental dalam memulai usaha. & 0,901 \\
\hline ED3 & $\begin{array}{l}\text { Saya harus tetap tenang ketika sedang menghadapi kesulitan dalam } \\
\text { bisnis. }\end{array}$ & 0,914 \\
\hline ED4 & $\begin{array}{l}\text { Saya dapat menemukan solusi ketika terjadi masalah. } \\
\text { ED5 }\end{array}$ & $\begin{array}{l}\text { Saya memiliki keyakinan yang teguh dalam keberhasilan } \\
\text { berwirausaha. }\end{array}$ \\
\hline
\end{tabular}




\begin{tabular}{|c|l|c|}
\hline KP1 & Saya memiliki kepribadian yang tegas. & 0,716 \\
\hline KP2 & Saya berani dalam mengambil resiko. & 0,800 \\
\hline KP3 & Saya mampu dalam memimpin orang lain. & 0,818 \\
\hline KP5 & Saya berorientasi kepada masa depan. & 0,851 \\
\hline FK1 & $\begin{array}{l}\text { Orang tua saya memberikan pandangan tentang bagaimana menjadi } \\
\text { seorang wirausaha sejak dini. }\end{array}$ & 0,615 \\
\hline FK2 & $\begin{array}{l}\text { Orang tua saya memberikan dukungan dalam pengambilan keputusan } \\
\text { untuk menjadi seorang wirausaha. }\end{array}$ & 0,796 \\
\hline FK3 & $\begin{array}{l}\text { Orang tua saya memberikan dukungan dalam bentuk modal untuk } \\
\text { memulai karir berwirausaha. }\end{array}$ & 0,848 \\
\hline FK4 & $\begin{array}{l}\text { Orang tua saya memberikan perhatian yang membuat saya } \\
\text { termotivasi untuk berwirausaha. }\end{array}$ & 0,780 \\
\hline NB1 & Saya senang berwirausaha. & 0,858 \\
\hline NB2 & Saya memiliki kesiapan untuk berwirausaha. & 0,758 \\
\hline NB3 & Saya memiliki pertimbangan yang matang untuk berwirausaha. & 0,894 \\
\hline NB5 & Saya lebih memilih karir sebagai wirausaha. & 0,836 \\
\hline NB6 & Saya selalu mencari informasi tentang bisnis. & 0,841 \\
\hline NB7 & $\begin{array}{l}\text { Saya lebih menyukai menjadi wirausaha daripada bekerja dengan } \\
\text { orang lain. }\end{array}$ \\
\hline Sumber: Pengolahan Data SmartPLS3.0
\end{tabular}

Sumber: Pengolahan Data SmartPLS 3.0

Berdasarkan hasil dari Tabel 2, telah menunjukkan bahwa seluruh indikator memiliki nilai loading factor di atas 0,60 dimana telah memenuhi syarat convergent validity. Hair et al. (2011) menjelaskan bahwa bila nilai loading factor diatas 0,6 maka dinyatakan valid, sehingga dapat disimpulkan bahwa semua variabel yang ada dalam penelitian ini dapat digunakan.

Tabel 3. Hasil Pengujian Reliabilitas

\begin{tabular}{|l|c|c|}
\hline \multicolumn{1}{|c|}{ Variabel } & Cronbach's Alpha & Composite Reliability \\
\hline Pendidikan Kewirausahaan & 0,810 & 0,875 \\
\hline Efikasi Diri & 0,889 & 0,920 \\
\hline Kepribadian & 0,808 & 0,874 \\
\hline Peran Faktor Keluarga & 0,758 & 0,848 \\
\hline Niat Berwirausaha & 0,914 & 0,933 \\
\hline
\end{tabular}

Sumber: Pengolahan Data SmartPLS 3.0

Berdasarkan hasil pengujian reliabilitas pada tabel 3, Hair et al. (2011) menyebutkan bahwa nilai cronbach's alpha dan composite reliability harus di atas 0,7 . Dalam penelitian ini seluruh nilai cronbach's alpha dan composite reliability di atas 0,7, maka dapat disimpulkan bawa data pada penelitian ini reliabel karena memenuhi kriteria dengan hasil yang berada di atas 0,7 . 
Hasil Uji Adjust $R$-Square $\left(\mathrm{R}^{2}\right)$

Tabel 4. Hasil Uji Adjust R-Square $\left(\mathrm{R}^{2}\right)$

\begin{tabular}{|c|c|}
\hline Variabel & Adjust $R$ Square \\
\hline Niat Berwirausaha & 0,868 \\
\hline
\end{tabular}

Sumber: Pengolahan Data SmartPLS 3.0

Dari hasil pada tabel 4, dapat dijelaskan bahwa hasil $\mathrm{R}^{2}$ dari niat berwirausaha sebesar 0,868. Artinya $86,8 \%$ variabel niat berwirausaha dapat dijelaskan oleh pendidikan kewirausahaan, efikasi diri, kepribadian dan peran faktor keluarga serta sisanya sebesar 13,2\% dijelaskan oleh variabel diluar penelitian contohnya jaringan bisnis, penggunaan teknologi, motivasi, kepemimpinan, pengetahuan kewirausahaan, Locus of Control, dll.

Hasil Uji $Q$-square $\left(\mathrm{Q}^{2}\right)$

Tabel 5. Hasil uji $Q$-square $\left(\mathrm{Q}^{2}\right)$

\begin{tabular}{|l|c|}
\hline \multicolumn{1}{|c|}{ Variabel } & Nilai $Q$-Square \\
\hline Niat Berwirausaha & 0.591 \\
\hline
\end{tabular}

Sumber: Pengolahan Data SmartPLS 3.0

Berdasarkan hasil yang ditampilkan pada tabel 5 , nilai $Q$-square dalam penelitian ini adalah 0,591. Berarti nilai dari predictive relevance $\left(\mathrm{Q}^{2}\right)$ lebih besar dari nol sehingga hubungan pendidikan kewirausahaan, efikasi diri, kepribadian, dan peran faktor keluarga dapat menjelaskan niat berwirausaha dengan baik dalam model penelitian yang telah dibuat pada penelitian ini karena nilai $Q$-square dari variabel niat berwirausaha lebih besar dari nol.

Hasil Uji Kecocokan Model (Goodness of Fit/GoF)

$\mathrm{AVE}=(0,638+0,699+0,636+0,585+0,700) / 5=0,537$

$\mathrm{GoF}=\sqrt{\mathrm{AVE} \mathrm{X} \mathrm{R}^{2}}$

$\mathrm{GoF}=\sqrt{0,537 \times 0,868}$

$\mathrm{GoF}=0.683$

Berdasarkan hasil perhitungan GoF yang dilakukan secara manual dengan kalkulator, maka dapat disimpulkan bahwa penelitian ini memiliki nilai GoF yang besar yaitu 0,683 , dimana nilai tersebut lebih besar dari 0,36 . 
Hasil Uji F-Square $\left(\mathrm{F}^{2}\right)$

Tabel 6. Hasil Uji F-Square $\left(\mathrm{F}^{2}\right)$

\begin{tabular}{|l|c|}
\hline \multicolumn{1}{|c|}{ Variabel } & F-Square \\
\hline Pendidikan Kewirausahaan terhadap Niat Berwirausaha & 0,054 \\
\hline Efikasi Diri terhadap Niat Berwirausaha & 0,727 \\
\hline Kepribadian terhadap Niat Berwirausaha & 0,064 \\
\hline Peran Faktor Keluarga terhadap Niat Berwirausaha & 0,079 \\
\hline
\end{tabular}

Sumber: Pengolahan Data SmartPLS 3.0

Berdasarkan pada Tabel 6, nilai F-Square sebesar 0,054, 0,064, dan 0,079 memiliki hubungan yang lemah. Sedangkan, nilai F-Square sebesar 0,727 memiliki hubungan yang kuat.

Hasil Uji Hipotesis (Path Coefficient)

Tabel 7. Hasil Uji Hipotesis (Path Coefficient)

\begin{tabular}{|l|c|c|c|}
\hline \multicolumn{1}{|c|}{ Variabel } & $\begin{array}{c}\text { Path } \\
\text { Coefficient }\end{array}$ & t-statistics & $p$-values \\
\hline $\begin{array}{l}\text { Pendidikan Kewirausahaan -> Niat } \\
\text { Berwirausaha }\end{array}$ & 0,145 & 2,326 & 0.020 \\
\hline Efikasi Diri -> Niat Berwirausaha & 0,514 & 8,308 & 0.000 \\
\hline $\begin{array}{l}\text { Kepribadian -> Niat Berwirausaha } \\
\text { Peran Faktor Keluarga -> Niat } \\
\text { Berwirausaha }\end{array}$ & 0,170 & 2,235 & 0.026 \\
\hline
\end{tabular}

Sumber: Pengolahan Data SmartPLS 3.0

Berdasarkan pada tabel 7, dapat disimpulkan bahwa hipotesis H1, H2, H3, H4 tidak ditolak artinya memiliki pengaruh positif dan signifikan.

\section{DISKUSI}

Dari hasil pengujian hipotesis variabel pendidikan kewirausahaan terhadap niat berwirausaha, memiliki nilai $t$-statistics sebesar 2,326 dan nilai $p$-values yang sebesar 0,020 , sehingga dapat disimpulkan bahwa pendidikan kewirausahaan memiliki pengaruh positif dan signifikan terhadap niat berwirausaha mahasiswa Universitas Tarumanagara. Hasil penelitian ini sejalan dengan penelitian oleh Puni et al. (2018), Blegur dan Sarwo (2020), Rauch dan Frese (2007), Lestari dan Wijaya (2012), Anggraeni (2016), dan Tsui (2013) yang menjelaskan bahwa pendidikan kewirausahaan memiliki pengaruh yang positif dan signifikan terhadap niat berwirausaha. Artinya pendidikan kewirausahaan sangat penting dalam meningkatkan niat berwirausaha mahasiswa karena Fatoki (2014) menjelaskan pendidikan kewirausahaan menjadi faktor penting dalam menumbuhkan dan mengembangkan keinginan, jiwa dan perilaku berwirausaha dikalangan generasi muda karena pendidikan merupakan sumber sikap dan niat keseluruhan untuk menjadi wirausahawan sukses di masa depan. 
Dari hasil pengujian hipotesis variabel pendidikan kewirausahaan terhadap niat berwirausaha, memiliki nilai $t$-statistics sebesar 8,308 dan nilai $p$-values yang sebesar 0,000 yang berarti $\mathrm{H} 2$, sehingga dapat disimpulkan bahwa efikasi diri memiliki pengaruh positif dan signifikan terhadap niat berwirausaha mahasiswa Universitas Tarumanagara. Hasil penelitian ini sesuai dengan Indarti dan Rostina (2014), Wijaya (2008), Puspitaningsih (2017), Bagheri (2013), dan Anggraeni (2016) yang menjelaskan bahwa efikasi diri memiliki pengaruh positif dan signifikan terhadap niat berwirausaha. Margahana dan Garika (2019) mengatakan bahwa seseorang yang memiliki rasa efikasi diri akan lebih mudah untuk membuat keputusan dalam membangun usaha itu sendiri karena individu tersebut yakin dengan kemampuan untuk beradaptasi terhadap lingkungan yang akan dihadapi.

Dari hasil pengujian hipotesis variabel pendidikan kewirausahaan terhadap niat berwirausaha, memiliki nilai $t$-statistics sebesar 2,235 dan nilai p-values yang sebesar 0,026 yang berarti H3 tidak ditolak, sehingga dapat disimpulkan bahwa kepribadian memiliki pengaruh positif dan signifikan terhadap niat berwirausaha mahasiswa Universitas Tarumanagara. Hasil penelitian ini sesuai dengan Pujiastuti (2013), Aprilianty (2012), Fitra Fajar Abdilah et al. (2013), Ayuningtias dan Ekawat (2015), dan Syaifudin (2016) yang menjelaskan bahwa kepribadian memiliki pengaruh positif dan signifikan terhadap niat berwirausaha. Alma (2011:79) menyebutkan bahwa karakteristik individu sangat berpengaruh terhadap keberhasilan usaha, dengan adanya pembentukan kepribadian wirausaha pada mahasiswa, akan berpengaruh positif terhadap niat mahasiswa dalam berwirausaha

Dari hasil pengujian hipotesis variabel pendidikan kewirausahaan terhadap niat berwirausaha, memiliki nilai $t$-statistics sebesar 2,435 dan nilai p-values yang sebesar 0,015 yang berarti H4 tidak ditolak, sehingga dapat disimpulkan bahwa peran faktor keluarga memiliki pengaruh positif dan signifikan terhadap niat berwirausaha mahasiswa Universitas Tarumanagara. Hasil penelitian ini sejalan dengan Leon et al. (2007), Routamaa dan Risman, (2003), Akanbi (2013), Triani (2010), dan Purnomo (2012) yang menyebutkan bahwa peran faktor keluarga memiliki pengaruh positif dan signifikan terhadap niat berwirausaha. Artinya keluarga memberikan dukungan kepada anaknya secara penuh agar dapat memberikan dorongan kepada anak-anaknya untuk menjadi seorang wirausaha.

\section{PENUTUP}

Berdasarkan hasil penelitian dari pengujian data dalam penelitian ini menunjukkan bahwa pendidikan kewirausahaan, efikasi diri, kepribadian dan peran faktor keluarga mempunyai hubungan yang positif dan signifikan terhadap niat berwirausaha mahasiswa Universitas Tarumanagara. Hal ini dapat terjadi karena pendidikan kewirausahaan, efikasi diri, kepribadian dan peran faktor keluarga merupakan komponen yang cukup penting dan dapat menciptakan niat berwirausaha bagi mahasiswa Universitas Tarumanagara.

Berdasarkan hasil penelitian ini, maka ada beberapa saran yang dapat diberikan oleh peneliti adalah sebagai berikut: (1) Universitas dapat mengadakan seminar ataupun sesi mentoring dengan menghadirkan para wirausahawan sukses sehingga mahasiswa/i dapat memahami proses nyata dunia kewirausahaan, mengidentifikasi karakteristik wirausahawan dan proses yang diperlukan agar menjadi sukses dalam dunia berwirausaha, dan termotivasi untuk menjadi seorang wirausahawan. Kegiatan ini dapat mengembangkan soft skill untuk melengkapi pengetahuan teoritis yang sudah diperoleh di perkuliahan. (2) Selain seminar Universitas juga dapat memberikan pendanaan bagi bisnis-bisnis baru. Universitas dapat 
melatih mahasiswa untuk menyakinkan para investor dan mengembangkan hubungan dengan para investor. (3) Disarankan kepada Universitas agar mengadakan suatu mata kuliah yang bertujuan untuk meningkatkan kepribadian, prestasi dan kemandirian yang ada dalam diri mahasiswa dalam niat berwirausaha. (4) Untuk penelitian selanjutnya diharapkan menambah jumlah sampel dan variabel penelitian, variabel penelitian yang dapat mempengaruhi niat berwirausaha antara lain akses modal keuangan, jaringan bisnis, penggunaan teknologi, motivasi, kepemimpinan, pengetahuan kewirausahaan, Locus of Control, dan lainnya. Karena semakin banyak sampel dan variabel yang ada maka data yang dihasilkan akan lebih bervariasi.

\section{DAFTAR PUSTAKA}

Ajzen, I. (1985). From intentions to actions: A theory of planned behavior. In Action control, 11-39. Berlin: Springer.

, (2005). Attitudes, personality, and behavior. United Kingdom: McGraw-Hill Education.

Alma, B. (2013). Kewirausahaan Untuk Mahasiswa dan Umum. Bandung: Alfabeta.

Aritonang R., L. R. (2007). Riset Pemasaran: Teori \& Praktik. Bogor: Penerbit Ghalia Indonesia.

Bandura, A. (1977). Self-efficacy: toward a unifying theory of behavioral change. Psychological review, 84(2), 191.

Badan Pusat Statistik. (2020). Tingkat Pengangguran Terbuka Berdasarkan Kelompok Umur, 2020 (Retrieved from: www.bps.go.id/5-11-2020)

Blegur, A., \& Handoyo, S. E. (2020). Pengaruh Pendidikan Kewirausahaan, Efikasi Diri dan Locus of Control Terhadap Intensi Berwirausaha. Jurnal Manajerial dan Kewirausahaan, 2(1), 51-61.

Boz, A., \& Ergeneli, A. (2014). "Women entrepreneur personality characteristics and parents parenting style profile in Turkey". Procedia-social and behavioral sciences, 109, 9297. DOI: $\underline{\text { https://doi.org/10.1016/j.sbspro.2013.12.425 }}$

Farrukh, M., Khan, A. A., Khan, M. S., Ramzani, S. R., \& Soladoye, B. S. A. (2017). "Entrepreneurial intentions: the role of family factors, personality traits and selfefficacy". World Journal of Entrepreneurship, Management and Sustainable Development, 13(4).

Ginting, M., \& Yuliawan, E. (2015). Jurnal Analisis faktor-faktor yang mempengaruhi minat berwirausaha mahasiswa. Studi kasus pada stmik mikroskil Medan. 5(1), 61-68.

DOI: https://doi.org/10.1111/j.1540-6520.2005.00099.x

Isabella, T. (2010). Theory planned of behaviour sebagai variabel anteseden faktor-faktor yang mempengaruhi intensi berwirausaha. Studi pada mahasiswa fakultas ekonomi manajemen. Universitas Sebelas Maret, Jawa Tengah.

Jonathan, S., \& Herlina, B. (2012). Statistik Terapan: Aplikasi Untuk Riset Skripsi, Tesis dan Disertasi (Menggunakan SPSS, AMOS, dan Excel). Jakarta: PT Elex Media Komputindo, Gramedia.

Karabulut, A. T. (2016). Personality traits on entrepreneurial intention. Procedia-Social and Behavioral Sciences, 229, 16-21. DOI: https://doi.org/10.1016/j.sbspro.2016.07.109.

Kuratko, D. F. (2005). The emergence of entrepreneurship education: Development, Trends, and Challenges. Entrepreneurship theory and practice, 29(5), 577-597. 
Lestari, Retno Budi dan Trisnadi Wijaya. (2012). Pengaruh Pendidikan Kewirausahaan Terhadap Minat Berwirausaha Mahasiswa di STIE MDP, STMIK MDP, dan STIE MUSI. Jurnal Ilmiah Bisnis dan Kewirausahaan STIE MDP, 1(2), 112-119.

Notoatmodjo, S. (2012). Metodologi penelitian kesehatan. Jakarta: PT. Rineka Cipta.

Nurchotim Lukman Hidayatullah. (2012). "Minat Berwirausaha Program Studi S1 Pendidikan Teknik Elektro Jurusan Teknik Elektri Fakultas Teknik Universitas Negeri Semarang”. Skripsi. Universitas Negeri Semarang, Jawa Tengah.

Rauch, A., \& Frese, M. (2007). Let's put the person back into entrepreneurship research: A meta-analysis on the relationship between business owners' personality traits, business creation, and success. European Journal of work and organizational psychology, 16(4), 353-385. DOI: https://doi.org/10.1080/13594320701595438

Yamin, S., \& Kurniawan, H. (2009). SPSS Complete: Teknik Analisis Statistik Terlengkap dengan Software SPSS. Jakarta: Salemba Infotek.

Zhao, H., Seibert, S.K. \& Hills, G.E. (2005). The mediating role of self-efficacy in the development of entrepreneurial intentions. Journal of Applied Psychology, 90(6), 12651272. DOI: https://doi.org/10.1037/0021-9010.90.6.1265 